\title{
Camping Sites State and Development Potential along the Bulgarian Black Sea Coast
}

\author{
$\mathrm{PhD}$ candidate Filip Marinov \\ University of Economics - Varna, Varna, Bulgaria \\ marinovfilip@ue-varna.bg
}

\begin{abstract}
Aim of the report is to enlist and classify regulated, non-regulated and potential camping grounds along the Bulgarian Black Sea Coast as well as to analyze their actual state and condition in high season. The observation research has been made from the northernmost to the southernmost points of the coastline during high season of 2019 from July to September. Classification has been made on size and type of camping ground. Non-regulated campsites have been measured for their size and counted for their population. Potential camping grounds have been chosen by the proximity to sea, tourism activity and benevolent surrounding criterias. Suggestions for future research on camping tourism have been made.
\end{abstract}

\author{
Keywords: Camping ground, Campsite, Bulgarian Black Sea Coast, Camping tourism \\ JEL Code: J30; doi:10.36997/IJUSV-ESS/2019.8.2.198
}

\section{Въведение}

Нарастващия интерес сред българското население към къмпинг туризма, по-скоро възраждащия се такъв, се дължи на ред причини. Тези причини се крият в различни по мащаб процеси и тенденции, както глобални и регионални така и локални. Урбанизирането на държавите и стила на живот на съвременния гражданин осезателно отдалечава човека от природата. Желанието за контакт с естествена среда го тласка към търсене на връзка с природата през свободното му време. Откритото, незамърсено от градска светлина, нощно небе, светулки и тишината на природната среда все повече ще набират популярност сред уморените от пренаселени и шумни хотели туристи. Неминуемо обществения интерес към къмпинг туризма поражда и академичния интерес към този вид алтернативен туризъм. В Европа среден дял на нощувките прекарани в къмпинги от всички туристически нощувки е $12 \%$, като Дания е лидер с 33\%, а България е с незавидните приблизително 2\% (Eurostat, 2019). Броят на къмпингите в цяла България, според Евростат (Eurostat, 2017), през 2016 е бил 11, а през 2017 са 9 бр. Според регистьра на "Места за настаняване и заведения за хранене и развлечения" към Министерството на Туризма (МТ, 2019) къмпингите в България са 49, а през 2017 г. са били 21 бр. (Маринов, 2017). В информационен сайт за къмпингите в България има информация за 53 къмпинга (Camping.bg, 2019). Разликите в броя къмпинги от различни източници на информация както и обективността при академичното изследване на къмпингите обосновават целта на настоящото изследване, а именно да се установи реалното състояние на къмпинг туризма по Българското Черноморие включващ в себе си регламентираните и нерегламентираните къмпинги. За целта авторът провежда обхождане от най-северния плаж до най-южния, плажовете като туристически ресурс са основна цел на практикуващите къмпинг край Черно Море през летния сезон. Описването и наблюдението са проведени в периода юли-септември 2019 г., за да се установи степента на заетост в силен сезон. Насочваща информация за съществуващите и потенциални къмпинги и биваци е получавана с помощта на: списък с къмпинги извлечен от интернет сайта camping.bg, навигационно приложение на мобилен телефон, на което има обозначени къмпинги(обозначаването става след преценка на собственика чрез самооценка), пътни указателни табели, преценка на автора съобразена с наличието на туристически природен ресурс и подходяща инфраструктура. Описаните спомагателни средства поставят изследователя в ситуация сходна на начинаещ турист, желаещ да къмпира или къмпингува. Ето защо всички наблюдения и анализи не могат да претендират за изчерпателност по 
отношение обекта на изследване, а именно къмпинг туризма по Българското Черноморие. Финансовите и физически възможности на автора не са достатъчни за създаването на детайлна справка за състоянието на антропогенните и природни ресурси необходими за къмпинг туризъм.

\section{1. Географско, структурно, икономическо и концептуално описание на къмпинг образуванията и потенциалните такива в северното Българско Черноморие}

Краткото описание на публично достъпна информация за всяко едно къмпинг образувание е структурирано по географски признак, като Българското Черноморие е условно разделено на северно и южно. Северното Черноморие е от нос Сиври Бурун до нос Емине и южното е от с. Резово до нос Емине. Структурирането на обектите по географски признак е направено в последователна позиция на обектите от север към Стара планина и от юг към Стара планина. Наименованията на районите, в които се позиционират обектите, са заимствани от справочник с наименования по Българското Черноморие (Трифонов, 2003).

Изследването започва от най-северната достьпна точка на Българското Черноморие, а именно Зона за бивакуване ${ }^{1}$ Дуранкулак. В Разположен е в зона „Дренака““ (Трифонов, 2003), пред северния плаж на Дуранкулак- граничарския плаж. Представлява тясна ивица от 50-70 м. горски масив разделящ земеделските площи от плажа. Подходящ е предимно за разполагане на палатки, трудния достъп за каравани и кемпери е поради влошения път до бивака. По пьрвоначална идея и проект са осигурени контейнер за смет с регулярно извозване на отпадъците и химическа тоалетна за нуждите на туристите, по настоящем такива не съществуват. Таксата за използването на 10 квадратни метра за денонощие е 3 лв., заплаща се в кметството на селото или се събира на място. Зоната е постановена, както останалите от този тип, през 2016 г.

Следва Къмпинг Космос, който е разположен между Карталийско блато и Картал бурун (Трифонов, 2003) с територия от 10 дка, по сведения от собствениците, изграден е преди 1989 г. като впоследствие е реновиран и поддържан. Къмпингът е категоризиран и регистриран, работи целогодишно, но заетостта е предимно през летния сезон. Управлява и се поддържа като семеен бизнес. Разполага с 30 бунгала, приблизително 100 места за палатки и 50 места за поставяне на каравани и кемпери, като 20 от тях са с по-голям размер за кемпери и по-големи каравани. Към къмпинга има функциониращ ресторант и 2 бр. кухни на самообслужване, санитарни възли с бани както и алеи свързващи отделните зони на къмпинга. Настаняването в бунгало струва 30/40 лв. за бунгало в зависимост от размера и удобствата, разполагане на палатка е 10 лв., за кемпер или каравана се заплаща 10 лв. плюс 10 лв. за човек. Следващата зона за къмпинг туризъм е между нос Крапец и Вадата-район Сърт яр (Трифонов, 2003) разположена по дължина на 4.3 км и средна ширина от 300 м, което е 129 хектара. В тази зона са разположени Къмпинг Крапец, Зони за бивакуване Крапец и нерегулирана Зона за диво бивакуване Крапец.

Къмпинг Крапец е разположен на територия от 39 декара и е построен в края на 60те и началото 70-те години на 20-ти век със 120 бунгала, голям магазин за хранителни и битови стоки, ресторант, и дискотека, но с годините голяма част от тях са станали силно амортизирани. През 2015 година започва поетапно възстановяване на къмпинга в първоначалния му вид. Ремонтирани са 40 бунгала и три санитарни помещения с бани и тоалетни. Създадени са условия за разполагане на палатки, кемпери и каравани и подвързването им към ток и вода и интернет. В момента къмпингът разполага с 180 места за палатки, 50 места за кемпери и каравани и 40 бунгала. Къмпингът е разположен в найсеверната част на Българското Черноморие и отстои на 2 км. северно от село Крапец

\footnotetext{
1 Мястото за бивакуване е част от местата в община Шабла разрешени за къмпингуване. Чрез наредба за опазване на обществения ред, община Шабла забранява дивото бивакуване и къмпингуване като за целта определя места за извършване на такъв род дейности
} 
(“Къмпинг Крапец,” 2019). Цените са: за бунгало - 58 лв., кемпер/каравана - 12 лв. плюс 10 лв. на човек, палатка - 10 лв. за човек ${ }^{2}$.

Около оградения къмпинг са разположени Зона за бивакуване Крапец и Нерегулираната къмпинг зона, разграничаването им, по мнение на автора, е направено с разликата, че при дивото бивакуване, туристите разполагат своите средства за настаняване върху дюните или самия плаж. По време на огледа са преброени 60 палатки, 20 кемпера, 9 от които с чужда регистрация и 70 каравани, 16 от които с чужда регистрация. Заетостта на плажната ивица в активен плажен период е около 15\%, което подсказва за потенциала за използване на туристическия ресурс.

Бивак Езерец е разположен в район Балтата на територията от 1 декар, представлява борова гора разположена успоредно на брега, който е издигнат над плажа и морето. В южния край на бивака, до пътеката за плажа има заведение за хранене и пиене. При огледа на бивака са преброени 65 палатки, 3 кемпера и 2 каравани. Натовареността на зоната е около $40 \%$. Цената за 10 квадратни метра е както при останалите зони за бивакуване в община Шабла. В района Кум Тепелер (Трифонов, 2003) на север от Шабленската Тузла е разположен бившият Къмпинг Добруджа, в момента на огледа къмпинг туризъм не е забелязан. От бившия къмпинг са останали названието на района и бунгалата. В южната част на село Тюленово е разположен следващата общинска

Зона за бивакуване Тюленово, тя се намира в незалесена площ на открито върху скалите над морето. Неприветливостта и липсата на минимални удобства определя липсата на посетители. В местност Иканталъка е разположен

Къмпинг Свети Георги, той е част почивен комплекс Свети Георги. Къмпинга работи целогодишно, разположен е върху площ от 25 декара на самият бряг на морето с осигурен пряк достьп до дълга 1 км плажна ивица. Разполага с над 200 къмпинг места, които имат достьп до захранване с електричество и вода. Има изградена голяма баня с тоалетни за лятно ползване, а за любителите на къмпинг през по-студените дни има нова баня с тоалетни за целогодишно ползване. Има осигурени условия и охрана за целогодишно оставяне на каравани в къмпинга. Целият къмпинг е захранен с лечебна минерална вода. Цената за кемпер/каравана е 40 лв. а за палатка е 30 лв. Амфитеатралното разположение на комплекса предоставя гледка към морето от всяка една позиция. Къмпингът предлага допълнителни услуги като басейн, ресторант, масаж и водни спортове (“Кьмпинг Св. Георги,” 2019).

В същата местност се намира Къмпинг Ботуша, той е изграден през 2018 г., но е официално открит през 2019 година. Той се намира съвсем близо до Балчик и Каварна и много близо до к-г Свети Георги. Отстои на около 100 м. от плажа. Локацията му е отлична за хората, които тьрсят тихо и спокойно място, чисто, ново и подредено, с добра вертикална планировка и разнообразие от вече добре познатите къмпинги у нас.Санитарните възли са от контейнерен тип. За сезон 2019 ще бъде изградена открита зона за миене на съдове. Ще разполага с перална машина, wi-fi, детска площадка, барбекюта под наем, плащане с банкова карта, и разбира се - място за обслужване на химически тоалетни. Част от територията му ще бъде залесена, за да отговори и на очакванията на търсещите повече сянка. Местата ще бъдат сепарирани (Camping.bg, 2019). Цената за разполагане на каравана е 35 лв.

Движението на юг в търсене на къмпинг образувание с помощта на "google maps" приложение показва резултати като къмпинг Бисер в гр. Балчик, който представлява паркинг или къмпинг Добруджа, който вече разгледахме, както и къмпинг Албена, което представлява масивни бунгала с нулева възможност за разпъване на палатка или паркиране на каравана. Това заблуждение се дължи на свободната употреба на думата къмпинг поради нейната не дотам ясна и/или непозната за голяма част от населението дефиниция.

Следваща реална спирка за къмпинг туризъм е Къмпинг Лагуна, той е разположен в северната част на к.к. Златни Пясъци. Вилно селище Лагуна принадлежи към групата на

\footnotetext{
${ }^{2}$ Цените, извлечени за всички къмпинги, посочени в изследването са за висок сезон около 20 август
} 
новите къмпинги в България. Той е сред най-предпочитаните места за отсядане по северното крайбрежие от чуждестранни туристи „на колела“- мотористи, велосипедисти, кемперисти и други заради добрите условия, които предлага за къмпингуване. Освен с къмпинг инфраструктура от модерен тип, комплексът разполага с ресторант, детски кът, снек бар, вили от средиземноморски тип и собствен плаж. Теренът е терасиран, което прави местата сепарирани едно от друго и силно уединени (Camping.bg, 2019). Цените за каравана и кемпер са 34 лв. плюс 8 лв. на човек, разпъването на палатка струва 10 лв.

Южно от гр. Варна в кв. Ракитника е разположен Екоклуб Варна с капацитет за настаняване до 80 човека. Предоставя стационарни палатки под наем и площи за разпъване на собствени. Предпочитан от любителите на спокойствието сред природата.

В северната част на к.к. Камчия е разположен комплекс Нептун на 25 км. южно от град Варна при устието на река Камчия и е част от природния резерват „Лонгоз“. Къмпинг Нептун е разположен на площ от 10 декара сред красивата вековна гора и виещи се лиани на Лонгоза и се намира на 300 метра от плажа. Комплексът разполага със 110 легла,в два вида бунгала и обособен, охраняем къмпинг за палатки и каравани с бани,тоалетни и електричество. Цената за бунгало е 40 лв. а цената за разполагане на къмпинг средство не е посочена в сайта на комплекса (“Къмпинг Нептун,” 2019).

По-близо до река Камчия от северната й страна е разположен Къмпинг Рай. Той предлага настаняване в бунгала, както и традиционно къмпинг настаняване. Двете са на различни локации - мястото за кемпери, каравани и палатки е на първа линия зад плажа, докато бунгалата са по-навътре в гората, по пътя. Мястото предлага сянка и има красива гледка към морето. Местата за къмпингуване са около 50 броя. Като информация за броя и ценоразписа не е предоставена на сайта, бройката е по усмотрение на автора.

На юг от устието на р. Камчия се намира плаж Камчийски пясъци, той е част от найдългата пясъчна ивица на българското Черноморие и се намира в едноименната защитена местност. Ивицата е условно разделена на три плажа. Плаж Камчийски пясьци започва от устието на река Камчия на север и лежи по средата на ивицата между плажовете Шкорпиловци и Камчия. Уникален е за българското Черноморие със своите непокътнати пясъчни дюни, навлизащи на места над сто метра в сушата и с девствената природа наоколо. Между дюните и горския масив съществува асфалтов път в добро състояние. На места се наблюдават останки от бетонни основи на различни сгради, което предполага присъствието назад във времето на туристически комплекс, предполагаемо къмпинг с големи размери. Позадълбочено изследване предполага търсене в държавен архив и различни научни и популярни източници на информация за туристическата дейност в района. За целите на настоящото изследване ще кажем само, че районът представлява интерес за любителите на свободното къмпингуване. Чести посещения в активен сезон и към края на летния сезон показват отлично саморегулиране при къмпиращите там туристи. следи от техния престой почти не се забелязват. Община Аврен, на чиято територия се намира зоната, е разположила табели с указания за спазване на чистотата и реда в района. Казани за отпадъци не се наблюдават.

Къмпинг Шкорпиловци е един от най-новите къмпинги в България. Той отвори врати през 2018 г. Разположен е на площ от 6000 кв.м. на първа линия зад плажната ивица на курорт Шкорпиловци, само на 200 метра от морската вода. Макар краткото си съществуване до този момент, къмпингът вече привлече вниманието на западните експерти по къмпинг и караванинг туризъм. Къмпинг Шкорпиловци предлага 61 места за настаняване на каравани, кемпери и палатки, като местата за каравани и кемпери са с размер около 75 кв.м., а тези за палатки около 35 кв.м. Всяко едно място има достьп до питейна вода и електричество. Цените за разполагане на кемпер/каравана са 20 лв. плюс 7 лв. за възрастен а за палатка 12 лв. плюс 7 лв. за възрастен., употребата на ток се заплаща допълнително.

Къмпинг Зора е от поколението нови къмпинги, създаден преди 10-тина години. Той се намира в центъра на гр. Обзор на площ от 5 декара, но на тихо и уединено място, така че 
да се почувствате максимално близо до природата. Отдалечен е от плажа на 150-200 м. Разделен е условно на 2 части - вилна зона, разполагаща с бунгала и двуетажна вила и къмпинг зона. Част от местата в къмпинг зоната са сепарирани едно от друго с естествен плет и са сенчести. Всяко от тях е водоснабдено и електро-захранено. Отделно има и голяма поляна за кемпер групи. Зора е един от най-модерните и добре поддържани къмпинги в България. Той е задължителна спирка на чуждестранните авто-туристи, не само заради прекрасните условия, но и заради гостоприемния персонал (Сamping.bg, 2019). Цените са 26 лв. за кемпер, 20 лв. за каравана и 12 лв. за палатка плюс 8 лв. за човек при всички настанявания.

Къмпинг Чайка се стопанисва от Военно почивно дело към Министерство на отбраната. Намира се извън град Обзор, по пътя за Бургас. Той също е разделен на две зони бунгала, които се ползват изцяло от служители на МO, и къмпинг зона за палатки и каравани, която е със свободен достъп за лица извън системата на Министерството. Санитарните възли са реновирани, към къмпинга функционира малко заведение. Отличителното е, че се намира в гъста гора - сянка, която няма да намерите никъде другаде в къмпингите по морето. Но този лукс си има цена - плажът е на 800 м. Малък и спокоен е, рядко посещаван от външни хора. Разполага с 60 места за палатки и 2 обособени за кемпери и каравани.

Къмпинг Иракли е наследник на част от старият голям къмпинг изграден и експлоатиран преди приватизацията след 1989 г., но е напълно модернизиран. Той разполага с няколко бунгала, къщички за гости с веранда и открита кухня, както и две зони за кемпери каравани и палатки. В условно наречената задна зона местата са подходящи за каравани и кемпери. Към всяка единица има колонка за ток, чиста вода и тръба за отпадна вода. Предната част на къмпинга представлява обширна поляна с млади дървета, без достьп за автомобили. Това е палатковата зона, която също е електрифицирана и водоснабдена. Санитарните възли на къмпинга са нови и поддържани. Има перална машина. На разположение на гостите е и външен кът за готвене и хранене, който разполага със скара, микровълнова фурна, посуда за готвене и хранене, в това число и чаши, чинии, прибори и др. Помислено е за най-малката прищявка на гостите, които искат да се самообслужат - има и въглища, подправки, сол и олио. Към къмпинга функционира и изключително добре зареден хранителен магазин, предлагащ дори био продукти. Къмпинга предлага 6 места за каравани и кемпери и 30 места за палатки на цени от 15 лв. за каравана/кемпер и 10 лв. за палатка плюс 8 лв. на човек. След като достигнахме до условния център на Българското Черноморие от север към юг, следва другата част, която започва от най-южната точка на Българското Черноморие към същия център на изследваната територия.

2. Географско, структурно, икономическо и концептуално описание на къмпинг образуванията и потенциалните такива в южното Българско Черноморие

Къмпинг Силистар е най-южния къмпинг разположен до едноименния плаж в горска среда. Районът е защитена местност и е част от Природен парк Странджа и е в погранична зона. С площ от приблизително 10 декара той предлага места за настаняване на 200 души. Настаняването е в собствени палатки, каравани и кемпери, като се предлагат 7 каравани под наем. Общите помещения и удобства са санитарните възли, бани, кухни, мивки, беседки и огнища. Цената е 10 лв. на човек за нощувка независимо от средството за нощуване и престой. Токът се произвежда чрез соларни панели и горивни генератори и е с ограничено използване от гостите, предимно за телефони и нощно осветление. Прясна вода и канализационна система съществува благодарение на съществуващата в миналото свинеферма в зоната. Въпреки липсата на модерни удобства къмпингът печели класацията на camping.bg за любим къмпинг по Черноморието, чрез анкета проведена сред активно къмпингуващи туристи.

Къмпинг Морски рай е разположен в северната част на плаж Ахтопол и разполага с каравани за настаняване на 40 души. Разполага предимно със стационарни каравани и 
няколко места за поставяне на собствено средство за подслон. Пазарен вариант на наименуване на този тип къмпинги е „каравани под наем“, тъй като по-голямата част, в някои случаи всички, от караваните са поставени за дълъг период с изградени около тях удобства като навеси, веранди, тоалетни и кухни в зависимост от предоставената инфраструктура и етапа на развитие или еволюирането на караваната. Цената за нощувка на човек е 10 лв. при наемане на цялата каравана. Цена за дългосрочно поставяне е 1200 лв. на година.

Къмпинг Делфин е разположен на Папийско дере в северния край на Ахтополски плаж също известен като плаж Лардиго с приблизителна площ от 1.4 хектара разделена на две условни площи. В едната част са разположени предимно палатки и няколко леки каравани поради трудния достьп, а другата разполага със свободни места за каравани и кемпери както и стационарни каравани и бунгала. Има ресторант както и общи кухни. При огледа на къмпинга са преброени около 120 палатки, 3 каравани, 2 кемпера, приблизително 50 стационарни каравани с подобрения както и 30 стари бунгала. Хигиенните условия в старите общи бани и тоалетни по мнение на автора са с ниско ниво, от друга страна има нови изградени с добро състояние, но отдалечени от палатковата част. Цените са: за оборудвана или стационарна каравана 60 лв., за бунгало 45 лв., за кемпер 14 лв., каравана 12 лв. и палатка 7 лв. за всички плюс 3 лв. на човек плюс 2 лв. за ток. От север къмпинга граничи с бивш нудистски плаж.

Следващото място с потенциал за къмпингов туризъм се намира между село Варвара и Черно море. В тази зона се намират 2 големи поляни с приблизителна площ 100 декара. Те предлагат изглед към морето и отличен морски климат, но за сметка на това в близост няма големи плажове а няколко трудно достъпни малки такива. Пример за това е разположеното в средата на едната поляна ваканционно селище Хачико, което всъщност е изградено от големи каравани дълготрайно разположени с подобрения-веранди навеси, беседки и кухни. Следвайки рядко срещаните табели за локация на къмпинг, в началото на гр. Царево, стигаме до Къмпинг-бунгала Нестинарка, в който практически няма възможност за практикуване на къмпинг туризъм. На север се намира трудно за описание и подредба къмпинг образувание. Става дума за района около плаж Арапя.

В покрайнините на района около плажа са разположени Къмпинг Бриз и Къмпинг Зона Кракен, те са разделени от една ограда и са с приблизителна площ 2 декара всеки. Разположени са в стара борова гора и предлагат стационарни устроени каравани за 50/60 лв. за нощувка, място за каравана за 35 лв. на денонощие и място за палатка 10 лв. Навлизайки по навътре към централния къмпинг ситуацията с локализирането на къмпинги става сложна. Според camping.bg в района на Арапя има два къмпинга- зона Кракен и Арапя-тополите. Арапя-тополите по описание се намира на пьрва линия на плажа и предоставя места за настаняване. За съжаление при изследването не беше открит подстьп и указателни табели до вход или рецепция на къмпинга. Според google maps, където регистрирането е по описание на собствениците, освен гореспоменатите, в зоната има още Къмпинг Арапя- Бунгала Борисови, терен за палатки и каравани, Къмпинг Арапя „При Мико“ и Караванен Къмпинг. Объркването при опита за локализирането им идва от липсата на разграничителни ограждения, портали и указателни и информационни табели, както и териториите между тях са изпълнени с каравани в дворове и частни имоти. По този начин цялата зона наподобява голям летен катун с гъсто разположени каравани и палатки. Ето защо автора смята за излишно по нататъшното изследване до изясняване на структурата и концепцията на конкретната зона, която от друга страна е очевидно ценен туристически ресурс, но с лошо менажиране.

Преди село Лозенец на плаж Верготи (Трифонов, 2003) разположен на приблизително 6 декара се намира Къмпинг Оазис. Изграден е на приватизиран къмпинг и разполага с административни и санитарни сгради. Управлява се от фирма ИФ Фаворит. Предлага под наем около 70 броя каравани с веранди, навеси и летни кухни, превърнати в бунгала. 
Стационарните бунгала са вероятно изградени на площи взети под наем за дълъг период от време и впоследствие преотдавани за по кратки срокове. Има и свободни места за гости със собствено средство за настаняване около 20 на брой. Според данни от сайта на къмпинга, той разполага с $60+$ места за настаняване, което е разминаване с видяното. Цените за къмпиране са: кемпер/каравана-15 лв., палатка- 9 лв., плюс 7 лв. за човек, бунгалата са средно по 65 лв. в зависимост от нивото.

Къмпинг „Кум Къшла“ се намират на 2 км. северно от село_Лозенец и граничи с къмпинг Юг. Плажната ивица се намира на 30 метра от него. На разположение на гостите е и заведение за хапване и пийване. Тук можете да опьнете палатка, да паркирате караваната си или да наемете такава, ако нямате собствена. Предлагат се също и бунгала под наем. Това място не е за туристи свикнали с лукса. Както във всички останали къмпинги по нашето Черноморие, и в този бунгалата са стари и са от времето на комунизма. Огледа на къмпинга установява преобладаващо наличие на стационарни каравани, което е в противоречие с обявеното в социалното пространство.

Къмпинг Юг е втори къмпинг в нашето изследване управляван от ИФ Фаворит. Разположен е на 1 км от град Китен и от устието на река Караагач до плаж Трипити. Къмпингът е разположен между два големи плажа - Юг и Корал и разполага с обширни зони за къмпингуване на палатки, каравани и кемпери. Къмпингът предоставя под наем бунгала, вили и каравани. Според информация от сайта предлага 160 места за настаняване, 13 бунгала и 3 каравани под наем. Достоверността на информацията не беше проверена, тъй като автора предполага същата форма на управление като при Къмпинг Оазис.

В съседство до Къмпинг Юг е разположен Къмпинг Якото място. Той предлага около 50 броя стационарни каравани под наем и приблизително 10 места за свободно настаняване. В къмпинга не се влиза с автомобили, изградени са пешеходни алеи и тревни площи. Предвижването се извършва както пеш така и с малки електромобили. Има ресторант и магазин с млад и приветлив персонал. Цените за палатка са 15 лв., за кемпер/каравана са 50 лв., а бунгалата-каравани са между 60-100 лв..

Преди река Караагач се намира Къмпинг Гардения (в google maps е известен като Къмпинг Лозенец) разположен до устието на река Караагач между Китен и Лозенец на площ от 96 дка първа линия с прилежаща плажна ивица. Разполага със 180 места за настаняване на каравани и кемпери, обособени като тераси с възможност за гледка към морето от всеки парцел. Всеки парцел е номериран, водоснабден, електрифициран и със собствен канал. Обособени са три зони: Зона за каравани, Зона за кемпери и Зона за бунгала. Санитарните помещения в Къмпинг Гардения са чисто нови и са разположени така, че да са максимално удобни за всички почиващи. В тях се поддържа отлична хигиена като се почистват по няколко пъти на ден. Всеки гост разполага с чип за достьп до санитарните помещения което гарантира поддържането на хигиената и използването им само от гости на къмпинга. Контролът на достъп, видеонаблюдението и живата охрана гарантират спокойствието на гостите на Къмпинга. Къмпинг Гардения е най-големият по Българското Черноморие и един от малкото категоризирани с издадено разрешение за поставяне на 180 бр. каравани и кемпери. Красивата природа и малкото застрояване наоколо, заедно с перфектната локация и достьп до главният път правят Къмпинг Гардения едно прекрасно място за почивка. Обновяването на Къмпинг Гардения през 2019 г включва построяване на чисто нови бани и тоалетни, построяване на мальк ресторант на брега на морето, облагородяване на парцелите и допълнително озеленяване на Къмпинга. Гостите на Къмпинг Гардения могат да използват безплатно чадър и шезлонг на плажа. На втори етап през 2020 г се предвижда изграждането на Супермаркет, който да е на разположение на гостите.

От другата страна на река Караагач се намира Къмпинг Китен разположен между южния плаж на гр. Китен и устието на река Караагач. Гостите имат възможност за избор между различни места за настаняване - под сянката на дърветата или на пясъка зад дюните, а непосредствената му близост до брега го прави любим за много туристи от България и 
чужбина. Къмпингът има самостоятелен паркинг, лекарски кабинет, детска площадка, магазин хранителни стоки, различни заведения за хранене и плажни барове. Къмпинг Китен разполага с 55 бунгала, 3 каравани под наем, 210 места за каравани и палатки места с възможност на подаване вода и ток. За тях е осигурени нов отделен санитарен възел с топла вода и външни мивки. Част от бунгалата се намират само на няколко крачки от плажа и са с капацитет от по три и четири легла, всяко от която има хладилник, самостоятелна баня с WC възел и собствена малка веранда. Останалите 40 бунгала са с две легла, без самостоятелна баня с WC възел. Къмпинг Китен предлага и каравани под наем. Предимствата на една наета каравана са явни: това е един удобен и същевременно евтин избор за почивка в близост до морето. Караваните предлагат всичко, от което се нуждаете. Санитарните помещения са на разстояние само няколко крачки. Те са с по 3 и 4 легла, разполагат със завивки, хладилник и малка веранда (Camping.bg, 2019). Ценообразуването е същото като при Къмпинг Юг, тъй като стопанисването е отново от ИФ Фаворит.

Къмпинг Атлиман се намира на 1 километър северно от град Китен и на 30 метра от прекрасния плаж на едноименния залив. Плажът е разположен на красив залив в северната част на Китен, заобиколен от гориста растителност. Новият къмпинг Атлиман беше официално отворен за посещение през юни 2018 г. Той е наследник на стария, общински къмпинг и е напълно обновен. Общата му площ е 14 дка и разполага със 150 места за палатки, кемпери и каравани, които се намират под гъстата сянка на дърветата. До всяко къмпинг място има електричество. Бунгала не се предлагат, но предстои да бъдат изградени. Атлиман разполага с две чисто нови сгради със санитарен възел. Те са модерно обособени, като във всяка от тях има помещения с тоалетна и душ. Умивалниците са в общата част на помещението. На едната страна на фасадата на всяка от двете сгради има външни душове за след плаж. Там се намират и мивките за миене на съдове. Обособено е отделно помещение с перална машина. Към къмпинга функционира добре зареден магазин за хранителни стоки. Цените са: палатка - 15 лв. плюс 5 лв. на човек, кемпер/каравана- 40 лв., каравана под наем50 лв.

Къмпинг Смокиня е разположен в район Каваците, южно от гр. Созопол. Към настоящия момент практически е разделен на два къмпинга - Смокиня и Форт Нокс. На юг от него се намира резервата Пясъчна лилия. Къмпинг Смокиня има няколко частни имота, които предлагат места за палатки, бунгала и каравани. В къмпинга има магазини и заведения за обществено хранене, както и възможност за морски спортове на плажа. Има редовен транспорт с влакче до Созопол.

В същата зона практически долепени един за друг е Къмпинг Каваци, той разполага с богата база за настаняване приблизително 400 места за палатки, каравани и кемпери, част от които са електрифицирани и водоснабдени и са разположени на сенчести места върху тревна настилка. Към къмпинга функционират хотел и бунгала. Бунгалата са не само морално а и физически остарели и са неизползваеми. Около тях приблизително с $90 \%$ заетост е запълнено с палатки, каравани и кемпери. Останалата част са стационарни каравани с подобрения. Къмпингът използва старата инфраструктура с алеи и пътеки. Разположен е в гора близо до плажа. Разполага със сепарета направени с естествена зеленина за каравани, кемпери и палатки. Санитарните възли изглеждат неподдържани и нехигиенични.

На север от гр. Созопол в южната част на Созополския залив се намира Къмпинг Златна Рибка е един от най-старите къмпинги по Черноморското крайбрежие в България. Разположен е в гориста местност в южната част на залива срещу о-в Св. Иван. Предлага места за настаняване на кемпери, каравани и палатки и разполага с бунгала и апартаменти. Къмпингът предлага на гостите си места за къмпиране на 150 каравани / кемпери и палатки, един апартамент и шест студиа (напълно обзаведени и оборудвани). Гостите на къмпинга ползват безплатно: душове, WC, както и интернет (WI-FI). Допълнително, на територията на къмпинга са разположени ресторант, павилион за палачинки,магазин за хранителни стоки и плодове и зеленчуци, фурна, лечебен център, масажи, магазин за спортни принадлежности и 
сувенири, водни атракциони и надуваем замък за деца. Плажът е охраняем от спасители и е снабден с всякакъв вид удобства като джетове, лодки, водни колела и сърф училище. Цената за каравана/ кемпер е 50 лв., за палатка е 35 лв. и включва едно къмпиращо средство (каравана/ кемпер/ палатка) - до 4 човека плюс МПС, както и ползването на електричество, вода и интернет (WI-FI). Допълнително се заплаща при регистрация на рецепцията на къмпинга, курортна такса на Община Созопол в размер на 0.40 лв./ човек на ден (“Златна рибка," 2019). Къмпингът е заобиколен от частни имоти, които по нерегулиран начин са запълнени с каравани и извършват туристическа дейност. На север по същия плаж са разположени няколко къмпинг образования, най-често наречени като „каравани под наем“, вероятно поради юридически причини свързани с категоризирането и търговската дейност на обектите.

Разположен на два километра западно от град Созопол на плаж Градина, Къмпинг Герен разполага с места за 30 каравани, 30 палатки и 5 бунгала. Сред сянката на гората и само на 30м от морския бряг, практически на пясъка можете да наемете оборудвани бунгала или да използвате обособените ни места за паркиране на каравани или кемпери. Къмпинга е от затворен тип, разполага с голям паркинг и подсигурено нощно осветление и охрана. Има бани и санитарни възли, кухненски кът с мивка и хладилник, маси и пейки за хранене, както и барбекю за свободно ползване. За най-малките гости е осигурен и детски кът.

Офшор Камп се намира в гората на залива Градина. Той е разположен на 3 минути пеша от плажа. Разделен е условно на три зони: зона за палатки, зона за кемпери и каравани и зона за хранене с ресторант. През 2018 г. в къмпинга е изграден чисто нов санитарен възел в зоната за палатки. Зона за палатки се намира в борова гора, на сенчесто, прохладно, тихо и уютно място. Зоната за кемпери и каравани е разположена на първа линия, непосредствено зад плажната ивица. На разположение на гостите без собствени средства за нощувка са оборудвани палатки тип Bell Tent и Pop-Up Tent, както и каравани под наем за 2, 3 и 4 души. Любителите на къмпингуването, които искат да го съчетаят с лукса, имат възможност да наемат луксозни каравани за 4 души. На гостите са осигурени удобства като обезпаразитен терен, нощно осветление, кът-кухня с мивка, хладилник, маси с пейки, огнище за свободно ползване и др. Топлата вода в санитарните възли е денонощна.

Глампинг Гора се намира на едно от най-красивите и популярни места на българското Черноморие, а именно къмпинг Градина. Разполага с 10 глампинг палатки с твърда основа и конвенционални легла. Самостоятелни санитарни възли към всяко бунгало не се виждат, следователно се ползват общите на къмпинга.

Къмпинг Градина е един от най-старите и известни къмпинги по Българското Черноморие. „Градина“ се намира в южната част на Българското Черноморие, в Созополския залив между градчетата Черноморец и Созопол на Царския плаж, по-близо до Черноморец, само на 30 км южно от Бургас. Достьпьт до него е от пьрвокласния пьт Бургас - Приморско. В къмпинга се предлагат места за настаняване както в собствени каравани и палатки, така и в луксозни бунгала. В къмпинга има няколко заведения за хранене, магазин за хранителни стоки, закусвалня, магазин за спортни стоки, както и банкомат. На плажа са обособени игрища за плажен волейбол, както и училища за уиндсьрф и кайтсьрф. За спокойствието на гостите е осигурена денонощна охрана от общинската полиция, а алеите са осветени и под видеонаблюдение. Къмпингьт е разположен на площ от 63 дка, с прилежаща плажна ивица от 60 дка и разполага с 168 места за настаняване на каравани, 21 за кемпери и 87 места за палатки. Разделен е условно на 4 зони, обособени в три линии спрямо брега на морето. Схема на къмпинг местата може да разгледате тук. Всички места са парцелирани и номерирани, като размерьт им е 80 кв.м. Всяко от тях е електрифицирано (до 2,20 kW) и водоснабдено. Тоалетните помещения в къмпинг „Градина“ са разположени така, че да са на максимално разстояние 50 м. от всяка къмпинг единица. Те са обновени и в тях се поддържа добра хигиена по няколко пьти на ден. Всеки гост разполага с ключ от баните и тоалетните, като по този начин се гарантира поддържането на чистотата им и използването им само от 
гости на къмпинга. Зоните за миене на съдове са на открито и са разположени през около 50 м. по дължина на алеите. Цената за парцел за каравана/кемпер е 40 лв., а за палатка е 30 лв.. Между град Черноморец и полуостров Атия се намира залива Вромос. До плажната му ивица в момента на изследване се намираха няколко сбирки на каравани и кемпери с общ брой приблизително 100. Плажът е неприветлив за туризъм, тъй като е със сив пясък, много водорасли, силно ветровит и има неприятна миризма. Въпреки тези негативи, наличието на къмпиращи до части беше обяснено със заниманието с кайтсьрфинг край брега и силния вятър.

Къмпинг Ахелой, комплекс "Ахелойска битка"се състои от къмпингите Лозана и Анастасия, но те са предимно запълнени с бунгала. Комплексът се намира южно от гр. Ахелой, недалеч от Бургас. Той предлага места за настаняване на кемпери, каравани и палатки. Площите са затревени и сепарирани. Част от тях са отделени едно от друго с дървени оградки, а други предоставят уют и уединение чрез жив плет. Всяко едно място е електрифицирано. Повечето се радват на естествената сянка на дърветата. Размерът им е между 40 и 60 кв. м. Санитарните помещения се намират в предната част на къмпинга. Баните са отделени от тоалетните, а зоната за миене на съдове е изнесена на открито. На разположение на гостите има топла вода денонощно. Къмпингът предлага и перална машина. Къмпинг Ахелой се намира на пешеходно разстояние от плажа.

\section{Заключение}

В заключение на изброените показатели на къмпингите по Българското Черноморие може да се обобщи, че къмпингите са разположени до плаж на максимум 200 метра от него. Големината им варира от 1 до 65 декара. Броят на местата за настаняване варира между 20 и 400 като преобладаващи са бунгала, каравани и кемпери спрямо тези за палатки. Цените за наемане на място са близки до цените за наемане на стационарни каравани и палатки, което предполага по-високо търсене и конкуренция в предлагането. Съответно тенденцията за увеличаване броя на стационарни каравани, като форма на глампинг туризъм, под наем е оправдана и вероятно ще се запази. Заетостта на къмпингите е над $80 \%$, дори и при незадоволителните хигиенни условия, от които често се оплакват туристите. Следователно изграждането на нови къмпинги-търговски или общински, както и реинвестирането в съществуващите такива, могат само да спомогнат за увеличението на дяла туристи избрали къмпирането като форма на отдих.

\section{References}

1. Camping.bg, 2019. къмпинги в България [WWW Document]. URL https://camping.bg/campings.html?location=България\&search=\&page=5 (accessed 11.10.19).

2. Eurostat, 2019. Camping tourism share.

3. Eurostat, 2017. accomodation statistics.

4. Zlatna Ribka [WWW Document], 2019. URL https://zlatna-ribka.com/\%0D

5. Camping Krapetz [WWW Document], 2019. URL https://krapecbeach.bg/camping/

6. Camping Neptun [WWW Document], 2019. URL http://campingneptun.com/къмпинг-2/

7. Camping Sv. George [WWW Document], 2019. URL https://saintgeorgesea.com/mm_campsite

8. Marinov, F., 2017. Problemi v razvitieto na kympingite po Bylgarskoto Chernomorie. Bourgas

9. MT, Ministerstvo na Turizma, 2019. Registyr na kympingi [WWW Document]. URL https://ntr.tourism.government.bg/CategoryzationAll.nsf/mn.xsp

10. Trifonov, Tr., 2003. Sedemstotin naimenovania po Bylgarskoto Chernomorie-Spravochnik. Varna Print. 